\title{
Die Blye Boodskap, vervreem
}

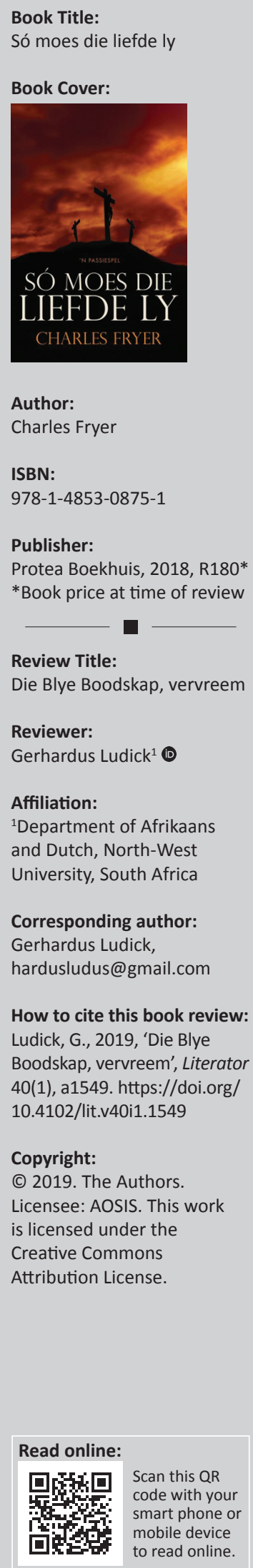

Charles Fryer se Só moes die liefde ly: 'n Passiespel is die eerste keer in 1988 onder leiding van Martina Rauch opgevoer as 'n gemeenteprojek in die Nederduitse Gereformeerde (NG) Kerk Parow-Panorama. Daarna is dit in die 1990's in die Kangogrotte by Oudtshoorn aangebied. In die huidige, gedrukte weergawe is daar ook liedere en danstonele ná die eerste opvoering bygevoeg.

Die passiespel kan as 'n subgenre van die religieuse drama beskou word en het gedurende die Middeleeue ontwikkel as 'n drama waarin die gebeurtenisse vanaf Christus se laaste maaltyd met sy apostels tot sy kruisiging uitgebeeld word. Dit het ná die Reformasie grootliks in onbruik geraak, maar die inherente dramatiese moontlikhede daarvan laat hierdie subgenre tog behoue bly.

Afgesien van die moontlikheid dat 'n outeur ondermynend met die konvensies van hierdie genre kan omgaan, weet die leser van 'n passiespel soos Só moes die liefde ly dus goed wat hulle te wagte kan wees. Uiteraard kan 'n mens 'n sekere mate van (woordelikse) getrouheid aan die Bybel en spesifiek die vier Evangelies verwag. So 'n teks kan dan nie slegs as drama op sigself beoordeel word nie, maar ook as passiespel wat binne sekere grense nietemin sonderling kan wees. Synde 'n passiespel vorm sekere gebeure (soos Christus se laaste maaltyd, die verhoor, die kruisiging, ens.) noodwendig die storie, en wel op 'n eerbiedige manier, maar daar is steeds beheer oor die verháál, naamlik oor hoe die storie aangebied word.

Boonop kan die seleksie van gebeure ook uitgebrei word, en Fryer kies eerstens om die verhaallyn uit te brei deur die apostel Johannes as raamverteller aan die woord te stel. Die proloog lees soos volg: 'Ek, Johannes, is na hierdie eiland verban omdat ek oor Jesus nie kon stilbly nie. [...] Hier op Patmos het Hy my in die gees weggeruk en my in die Verborgene laat sien' (bl. 11). Hy begin vertel van Christus, dat hoewel skares Hom gevolg het, niemand werklik die aard van sy koninkryk begryp het nie: ook sy dissipels het eers ná sy verheerliking begin verstaan. Die noem van Christus se intog in Jerusalem as 'n tyd toe die dissipels nog gedink het: 'Nóú gaan Hy die troon van Dawid vir Homself vat ...', lei die opvoering van hierdie toneel in. Johannes bly meesal as verteller tussen tonele teenwoordig en moet die agtergrond van tonele verskaf, of op 'n afgelope toneel kommentaar lewer.

Net minder as die helfte van die bladsye, en waarskynlik ook die speeltyd, beeld Jesus se aardse tyd vóór die laaste maaltyd uit: waar Hy die doofstom man genees, die bergpredikasie lewer, die tempel reinig, gesalf word, en so meer. Daar is dertig tonele, meesal drie bladsye lank. Die snelle tempo van die tonele voor die maaltyd val op, maar ten goede: dit klop met die gedurige vooruitskouing van die komende gebeure. Selfs die afwisseling met musiek- en dansitems speel saam in die boeiende momentum na die kruis.

Die Jesus wat mens in hierdie blaaie (of op hierdie planke sou) vind, is oortuigend en meesleurend mens - én God. Hy staan uit as meer méns as die apostels wat die kinders van Hom wil weghou, of as die klipgooiers en die priesterhoofde wat die owerspelige vrou wil stenig. Met die verhoor voor Kajafas laat sy min maar duidelike woorde, te midde van die priesterhoofde, raadslede, getuies en andere se geraas, hierdie leser weer opnuut onder die indruk van sy Andersheid kom.

By'n teks soos Só moes die liefde ly moet [hier]die resensent verskillende aanbevelings vir verskillende lesers maak. Die leser of toeskouer van byvoorbeeld Kaburu, Die naaimasjien, of Die seemeeu beskou hierdie werke nie as 'die uitbeelding van ' $n$ historiese werklikheid' nie, en hoef ook nie. By 'n Christelike werk soos Fryer s'n, is daar egter 'n noodwendige verskil tussen die leser wat dit as 'die uitbeelding van 'n historiese werklikheid' beskou, en dié wat dit as 'n mite benader.

Volgens my is die waarde van die teks nietemin sóórtgelyk, ofskoon verskillend wat die spesifieke aard betref, vir hierdie twee soorte lesers. Wat anders kan 'n teks, wat geen volstrek nuwe verhaal vertel nie, bied as vervreemding jeens ' $n$ bekende verhaal en insigte? Met vervreemding 
word dít bedoel wat die Russiese Formaliste van die vroeë twintigste eeu as 'n onderskeidende kenmerk van die letterkunde beskou, naamlik dat die letterkundige teks die leser se geoutomatiseerde waarneming van die werklikheid kan deurbreek om opnuut, op nuwe maniere, daarin te leef. Die leser wat Fryer se teks as uitbeelding van die werklikheid beskou, kan dus danksy vervreemding (deur die outeur se doelbewuste ordening, [her]verwoording, indrukwekkende oorspronklike liedere naas bekendes, en veral geslaagde dramatiese opvoering) na bekende waarhede terugkeer met nuwe oë en ore.

Dit is natuurlik 'n vraag sonder 'n antwoord of die groter vrymoedigheid met die Bronteks ook'n sterker vervreemding sou kon toelaat. Daar ontstaan naamlik'n effense ongelykheid wanneer woordelikse aanhalings (uit die 1933/1953- en 1983-vertalings) argaïes opklink langs 'n parafrase (soos wanneer Jesus vir die kinders op hulle vlak 'vertel wat naasteliefde is') asook by geskrewe dialoog. Laasgenoemde is juis ' $n$ aanwins vir die teks en werk geloofwaardigheid (en humor) in die hand, soos die vroue wat Jesus se opdrag om niemand te vertel van wat hulle gesien het nie, ignoreer: 'My kind, Hy is glads te nederig. Goeie nuus moet uit' (bl. 19) - of die vrou van Saggeus wat skepties is oor die klomp gaste vir ete: 'Wag, laat ek solank loop. As Hy nie vandag iets vermeerder nie, weet ek nie hoe hulle gaan vol kom nie' (bl. 42). Soms verleen dit weer direktheid wat Christus se Andersheid laat opval - een van dié wat die owerspelige vrou wil stenig, sê: ‘Kom ons gooi en kry klaar! Dit sal ander slette leer om nie rond te lê nie' (bl. 30).

Nietemin werk selfs hierdie ongelykheid ten goede mee deurdat sowel die nuwe woorde as die bekendes (omdat hulle herrangskik en opgevoer word) kristalhelder uit die vervreemdingsverf kom. Ek vermoed boonop dat iets verlore sou gaan indien iets anders gewen sou word deur ' $n$ vryer omgang met die Bybelstof - dit is soms beter om ' $n$ ou vriend opnuut te leer ken as om aan 'n vreemdeling voorgestel te word. Uiteindelik is dit juis Fryer se gematigde vrymoedigheid wat aan die teks sy waarde verleen.

Ook die lesers wat die teks as fiksie sou benader, kan egter aangeraai word om hulle aan hierdie vervreemding oor te gee, of minstens bloot te stel. Vir albei lesers dreig die inhibisies van die subgenre om die andersins goed geoliede trein te ontspoor, maar dit bly gelukkig by dreigement. Hoewel Só moes die liefde ly vir alle lesers aanbeveel kan word, is dit egter ook ' $n$ teks wat smeek om opgevoer te word, en wiens waarde ook in 'n groot mate van 'n goeie produksie afhang. 